WOJCIECH DUTKA

Uniwersytet Jagielloński

\title{
DUCHOWIEŃSTWO RZYMSKOKATOLICKIE I KATOLICYZM PŁASZCZYZNAMI SPORU O POWSTANIE STYCZNIOWE W POLSKIEJ HISTORIOGRAFII W LATACH 1863-1918
}

Po dziś dzień aktualne są słowa Sławomira Kalembki, który ponad dwadzieścia lat temu zauważył, że nie istnieje studium historiografii powstania styczniowego ${ }^{1}$. Tematyka niniejszego tekstu jest oczywiście wycinkiem tego zagadnienia; w centrum mego zainteresowania znalazł się spór o zaangażowanie duchowieństwa rzymskokatolickiego i rolę katolicyzmu w styczniowej irredencie, prowadzony w latach 1863-1918. Eugeniusz Niebelski, autor najobszerniejszej rozprawy poświęconej udziałowi duchowieństwa w powstaniu 1863 r., napisał, że literatura przedmiotu powstała do roku 1939 nosi generalnie cechy hagiograficzne, przedstawiając $\mathrm{w}$ wyidealizowanej formie patriotyzm, bohaterstwo i martyrologię uczestników powstania ${ }^{2}$. Ale to jedynie część prawdy. Opinia Niebelskiego nie może być zastosowana do silnego publicystycznego nurtu polskiej historiografii krytykującej zaangażowanie polskiego duchowieństwa w powstanie styczniowe.

Baza źródłowa niniejszego artykułu obejmuje dzieła tworzone przede wszystkim przez historyków amatorów. Niezależnie od tego, czy aspirowały one do statusu syntez historycznych, czy też były po prosu okazjonalnymi broszurami, cechowały się obecnością mocnego ładunku emocjonalnego i polemicznego. Przedłożony tekst jest badawczą propozycją analizy wybranych głosów najważniejszych uczestników tego dyskursu.

${ }^{1}$ S. Kalembka, Zamknięcie, w: Powstanie Styczniowe 1863-1864. Wrzenie, bój, Europa, wizje, red. idem, Warszawa 1990, s. 739.

${ }^{2}$ Por. E. Niebelski, Nieprzejednani wrogowie Rosji. Duchowieństwo lubelskie i podlaskie w powstaniu 1863 roku i na zesłaniu, Lublin 2008 (wyd. 2), s. 9. 


\section{W kręgu apologii}

Chciałbym rozpocząć od pracy Juliusza Stanisława Zborowskiego (18421870) pod znamiennym tytułem Krzyżowy charakter ruchu polskiego. Trzy charakterystyki, wydanej pod pseudonimem Juliusza Jastrzębczyka we Lwowie w 1864 r. To pierwszy duży tekst w całości poświęcony postaciom Kościoła katolickiego, opublikowany tuż po klęsce powstania. Narracja jest tutaj tak bardzo wypełniona wzniosłą kategorią sublime, tak głęboko zmitologizowana, że można uznać ją za paradygmatyczny przykład retorycznego przeistoczenia beznadziejnie przegranego powstania w wielkie chrześcijańskie zwycięstwo. Według autora powstanie styczniowe miało status równy krucjatom, czyli wojnom świętym; było w jakiś cudowny sposób bożą próbą, nacechowaną męczeństwem i wiarą katolicką. „Koleje, jakie naród w tym czasie przechodził, schodzą się tak ściśle z drogami kościoła, że pisarz ostatnich dziejów kościoła polskiego będzie musiał do swego obrazu malować krwawe tło narodowe"3.

Tekst prezentuje klasyczne motywy polskiej martyrologii: Polska była przedmurzem chrześcijaństwa, zawsze silna wiarą, a ruch narodowy skrył się pod płaszcz Kościoła przed brutalnymi atakami Moskwy:

Duchowieństwo polskie walczyło więc z całym poświęceniem przeciw caratowi i szyzmie. Walka to krzyżowa, do której nie występowali rycerze zbrojni, ale w której płynęła krew obficie, jak ongiś w cyrkach rzymskich, świadcząc wymownie o potędze tej idei, która we krwi ochrzczona, wznosiła się coraz wyżej i silniej poświęceniem i ofiarami ${ }^{4}$.

Według autora, zaangażowane w walkę duchowieństwo miało silne wsparcie wszystkich biskupów (co nie jest prawdą). W sposób z pewnością ahistoryczny, ale zgodny z logiką uwznioślającego mitu Polski Chrystusa narodów, prześladowania chrześcijan z czasów rzymskich oraz wyprawy krzyżowe z lat 1099-1291 zlewają się w ontyczną i narracyjną jedność. Celem duchowieństwa polskiego miała być walka przeciwko caratowi i schizmie prawosławnej. Natomiast zdystansowanie się Watykanu od powstania polskiego autor zbył uwagą, iż „Rzym nie zrozumiał ducha polskiego", a ojciec święty został zwiedziony szatańskimi machinacjami rządu moskiewskiego ${ }^{5}$. Zborowski przedstawił także hagiograficzne ujęcie trzech ważnych postaci Kościoła z czasów powsta-

${ }^{3}$ J. S. Zborowski [J. Jastrzębczyk], Krzyżowy charakter ruchu polskiego. Trzy charakterystyki, Lwów 1864, s.3.

${ }^{4}$ Ibidem, s. 9.

${ }^{5}$ Ibidem, s. 15. 
nia: arcybiskupa Zygmunta Szczęsnego Felińskiego, jego poprzednika na tronie arcybiskupów warszawskich Antoniego Fijałkowskiego oraz biskupa Antoniego Białobrzeskiego.

Podobne wątki hagiograficzne oraz kategoria sublime dominują w książce Duchowieństwo polskie wobec sprawy narodowej, której autorstwo przypisuje się „czerwonemu” księdzu Kasprowi Kotkowskiemu (1814$1874)^{6}$. Romantyczna, egzaltowana retoryka „Polski - Chrystusa narodów” jest podstawowym kontekstem interpretacyjnym, w którym należy czytać ów tekst. Autor już na drugiej karcie pisał, że „Polska dzisiaj jak Chrystus ukazuje swe rany. Stoi u słupa ubiczowana”. Kotkowski nawiązał do manifestacji patriotycznych, choć najważniejszym wydarzeniem dla niego było odnowienie unii Polski i Litwy w symbolicznej uroczystości, jaka odbyła się 10 października 1861 r. w Horodle 7 . Powstanie styczniowe stanowiło dla Kotkowskiego klęskę jedynie pozorną, w istocie miało dorównywać męczeństwu pierwszych chrześcijan pomordowanych za czasów Nerona i Dioklecjana ${ }^{8}$. Celem broszury Kotkowskiego była odpowiedź na dwa stawiane Kościołowi i duchowieństwu zarzuty odnośnie do 1863 r. Pierwszy z nich dotyczył tego, że okres manifestacji nie był przepełniony duchem religijnym, a drugi, że udział „duchownych w tych wystąpieniach był negatywny i naganny" ${ }^{\circ}$. Kotkowski konsekwentnie stał na stanowisku apologii zaangażowanego politycznie duchowieństwa. Twierdził, że nie sposób objaćc rozumem roku 1863, jeśli wyłączyć z niego pierwiastek religijny. Śmierć męczeńska tylu kapłanów „i tyle tysięcy wygnańców i więźni - duchownych” stanowiły „dowód z życia, śmierci i czynów, jaki duchowieństwo polskie brało udział w wypadkach w Polsce"10. Kotkowski twierdził także, że zaangażowanie duchownych w powstanie było dowodem jedynie na to, jak silnie sprawa narodowa łączyła się ze sprawą religijną. W jego przekonaniu „nie jest to żadne mieszanie się do polityki, jak często mówią, bo religii i spraw wiary nikt nie jest nigdy w stanie oddzielić od spraw narodowości i państwa"11. Książkę zamknął ponownie motywem męczeństwa i świętości, w którym Polska stała się nową Joanną d'Arc, umęczona w 1863 r. ,jak owa czysta dziewica Orleańska".

${ }^{6}$ Zob. S. Kieniewicz, Kasper Kotkowski, PSB, t. 14, Wrocław-Warszawa-Kraków 1970, s. 471-472.

${ }^{7}$ [K. Kotkowski], Duchowieństwo polskie wobec sprawy narodowej, Paryż 1865, s. 17-18.

${ }^{8}$ Ibidem, s. 23.

${ }^{9}$ Ibidem, s. 70 .

${ }^{10}$ Ibidem, s. 86.

${ }^{11}$ Ibidem, s. 90. 
Ciekawe wątki wprowadził do debaty Agaton Giller (1832-1877) ${ }^{12}$. W czasie powstania był członkiem Rządu Narodowego z ramienia białych, a po powstaniu dziejopisem i żarliwym jego obrońcą. W drugim tomie swego największego, nieukończonego dzieła Historia powstania narodu polskiego 1861-1864 r. napisał, że w czasie powstania styczniowego polskie duchowieństwo poszło właściwą drogą i nie odepchnęło narodu od wrót świątyni nawet w najczarniejszych chwilach ${ }^{13}$.Jako osobę odpowiedzialną za ów dobry i patriotyczny kierunek wskazał abp. Felińskiego (1822-1895) ${ }^{14}$. Początkowo ów hierarcha miał się znajdować na błędnej drodze (tj. lojalizmu), ale w końcu zrozumiał swój błąd i stał się przedstawicielem polskiej zasady dziejowej ${ }^{15}$. Dodajmy na marginesie, że w ową przemianę nie uwierzył autor najnowszej pracy traktującej o stosunku Kościoła katolickiego do nacjonalizmu i wyzwań modernizacji, Brian Porter-Szücs, który nazywał lojalizm Felińskiego „stałym i konsekwentnym” ${ }^{16}$. Omawiając anonimową broszurę, zatytułowaną Duchowieństwo polskie wobec sprawy narodowej, Giller streszcza jej główne myśli z pełną autorską aprobatą: „Autor w naszych bojach, męczeństwie, widzi spełnianą tę samą myśl, która ożywiała ojców naszych pod

12 O Gillerze: S. Pisarski, Spis dzieł Agatona Gillera, Przemyśl 1894; W. Siedlaczkówna, Agaton Giller, Paryż 1891; Z. Zygmuntowicz, Agaton Giller w świetle państw zaborczych, Lwów 1937; S. Kieniewicz, Agaton Giller, PSB, t. 7, Kraków 1948-1958, s. 467-470; Historiografia polska $w$ dobie pozytywizmu (1865-1900). Kompendium dokumentacyjne, red. R. Przelaskowski, Warszawa 1968, s. 66; H. Florkowska-Frančić, Emigracyjna działalność Agatona Gillera po powstaniu styczniowym, Wrocław 1985; J. Fiećko, Rosja, Polska i misja zesłańców. Syberyjska twórczość Agatona Gillera, Poznań 1997; M. Jarnecki, Powstanie styczniowe w oczach Agatona Gillera, „Mazowieckie Studia Humanistyczne” 10, 2004, z. 1/2, s. 5-32.

${ }^{13}$ A. Giller, Historia powstania narodu polskiego w 1861-1864 r., t. 2, Paryż 1868, s. 153.

${ }^{14}$ Literatura o arcybiskupie zarówno ta pochodząca z drugiej połowy XIX w. i XX w., jest bardzo bogata, zob. P. Prawdziwicki, Wspomnienie o Zygmuncie Szczęsnym Felińskim abpie metropolicie warszawskim, Kraków 1866; ks. I. Polkowski, Wspomnienie o księdzu Felińskim, arcybiskupie warszawskim, Kraków 1866; bp J. Pelczar, Mowa żałobna na pogrzebie Zygmunta Szczęsnego Felińskiego, abpa warszawskiego, Kraków 1895; ks. W. Smoczyński, Ksiądz Zygmunt Szczęsny Feliński, Kraków 1896; E. Jezierski, Arcybiskup Feliński, Warszawa 1911; A. Kraushar, Z życia abpa Zygmunta Szczęsnego Felińskiego, Warszawa 1916; M. Godlewski, Tragedia arcybiskupa Felińskiego (1862-1863), Kraków 1930; W. Malej, Ksiądz Arcybiskup Zygmunt Szczęsny Feliński, Rzym 1966; H. E. Wyczawski, Arcybiskup Zygmunt Szczęsny Feliński (1822-1895), Warszawa 1975; M. Aleksa, Sługa Boży arcybiskup Zygmunt Szczęsny Feliński, metropolita warszawski, Warszawa 1987; S. Gajewski, Solidarność i niepodległość myśli społecznej abpa Zygmunta Szczęsnego Felińskiego, w: Ojczyzna i wolność. Prace ofiarowywane prof. J. Ziółkowi w siedemdziesiąta rocznicę urodzin, red. A. Barańska, W. Matwiejczyk, E. Ziółek, Lublin 2000, s. 315-321.

${ }^{15}$ A. Giller, Historia powstania narodu polskiego w 1861-1864 r., t. 1, Paryż 1867, s. 238.

${ }^{16}$ B. Porter-Szücs, Faith and Fatherland, Catholicism, Modernity, and Poland, New York 2011, s. 161. 
Lignicą, Grunwaldem i Wiedniem; widzi krucjaty za wolność, postęp, cywilizację i religię"17.

Między polską walką o niepodległość a walką o obronę katolicyzmu zachodził w myśli Gillera ścisły związek. Ów związek opisała prawie trzydzieści lat temu Ewa Jabłońska-Deptuła, nazywając go religijną zasadą suwerenności narodowej ${ }^{18}$. Ta zasada była wyrażana w przekonaniu, że w czasie niewoli narodowej Polacy mogą poczuć się naprawdę wolni w Kościele ${ }^{19}$. Zbigniew Ćwiech stwierdził natomiast, że Giller bronił w sposób szczególny historycznej suwerenności narodu po upadku insurekcji styczniowej, kiedy przebywał na emigracji ${ }^{20}$. Giller argumentował, że nie można oddzielić katolicyzmu od polskości, bo nienawiść Moskali do Polaków nie ma charakteru narodowego, ale właśnie religijny ${ }^{21}$. W jego interpretacji owo powstanie było wojną tyleż narodową, co religijną ${ }^{22}$. Katolicyzm był ważną cechą odróżniającą Polaków od reszty Europy. To właśnie katolicyzm przekonywał Giller - sprawił, że ruch narodowy z lat 1861-1863 był inny niż wszystkie poprzednie polskie powstania ${ }^{23}$. Giller był też przekonany, że wiara wywyższyła naród polski; ,wiara zrobiła z niego tarczę dla Europy od Tatarów, Mongołów, Moskali i Turków"24. Przekonanie to należy ocenić w kategoriach mitu o wyższości narodu polskiego oraz roli Polaków jako przedmurza chrześcijaństwa ${ }^{25}$. Polacy mieli prezentować wyższy rodzaj moralnej kultury, której źródłem miała być wiara katolicka. Giller pisał, nie bez dumy, że „radykaliści europejscy [- ] nie znają [- - ] polskiej wiary"26, tzn. nie rozumieją, że w Polsce właśnie religia jest źródłem ideałów wolnościowych. Opierał się na przekonaniu, że „zachód” ogniskuje złe cechy. Jak przekonywał Jerzy Jedlicki, mit „czarnego”, czyli złego moralnie Zachodu zakorzenił się bardzo silnie w piśmiennictwie i publicystyce po

${ }^{17}$ A. Giller, op. cit., t. 1, s. 242.

${ }^{18}$ E. Jabłońska-Deptuła, Religijna ideologia suwerenności narodowej w XIX wieku, „Więź” 1982, 4/5, s. 6-22.

${ }^{19}$ Por. eadem, Aspetti nazionali e universali della religiosità patriotica Polacca, w: The Common Christian Roots of the European Nation. An International Colloquium in the Vatican, Florence 1982, s. 1077-1085.

${ }^{20}$ Z. Ćwiech, Powstanie styczniowe 1863, Warszawa 1963, s. 27-29.

${ }^{21}$ A. Giller, op. cit., t. 1, s. 239.

${ }^{22}$ Ciekawie pisze o utożsamieniu powstania 1863 r. z ideą katolicką B. Porter, odróżniając polski „ethno-Catholicism” od katolicyzmu definiowanego „either as a theological framework or as a religious institution”. Por. B. Porter-Szücs, op. cit., s. 167.

${ }^{23}$ A. Giller, op. cit., t. 1, s. 244.

${ }^{24}$ Ibidem.

${ }^{25}$ J. Prokop, Wschodnia straż Europy. Mit Polski strażniczki Zachodu, w: idem, Ethnos i Caritas. Idee - mity polityczne i literackie, Kraków 2001, s. 157-180.

${ }^{26}$ A. Giller, op. cit., t. 1, s. 244. 
klęsce 1863 r. ${ }^{27}$ Przy okazji Giller zarzucił Zachodowi niezrozumienie fenomenu polskiego równouprawnienia wyznaniowego:

Nie znają oni polskiej wiary - a zapomnieli, że pierwszym aktem tego narodowo-religijnego ruchu było równouprawnienie wszystkich wyznań zbratanie się z Żydami, jakiego przykładu ani Francja, ani Niemcy, Szwajcaria i Amerykańska respublika nam nie przedstawia. I odtąd widziano Żydów ginących w obronie krzyża [- - ]; widziano trzech katolickich biskupów oddających pokłonem, publicznie, na ulicy, cześć duchowieństwu żydowskiemu ${ }^{28}$.

Jako naczelny dowód, iż powstanie w 1863 r. nie było dziełem nacjonalistów, Giller przytoczył stosunek ruchu narodowego do Żydów, pełen zrozumienia i braterstwa ${ }^{29}$. Wyraził także przekonanie, że najniebezpieczniejsze jest określenie, że Polak musi być katolikiem. Polskość ograniczyć katolicyzmem, przekonywał Giller, jak „Moskale swoją narodowość prawosławiem", to znaczy podkładać pod budowę narodu minę, tak jak patriotyzm Katkowa niszczył imperium rosyjskie. Przywołanie postaci Michaiła Katkowa (Mihail Katkov), redaktora „Moskowskich Wiedomosti”, dziennikarza zaangażowanego w antypolską propagandę w 1863 r., nie jest przypadkowe ${ }^{30}$. Giller wyraził tym dystans do instrumentalnego łączenia nacjonalizmu z religią. Wyraził przekonanie, że przyszła niepodległa Polska musi być oparta na równouprawnieniu wyznań ${ }^{31}$. Dystansując się od modelu Polaka-katolika ${ }^{32}$, Giller wskazywał na fakt, że jedność polityczna narodu polskiego może być skorelowana z różnorodnością re-

${ }^{27}$ Zob. J. Jedlicki, Świat zwyrodniały. Lęki i wyroki krytyków nowoczesności, Warszawa 2000, s. 69; zob. idem, Polskie nurty ideowe lat 1790-1863 wobec cywilizacji Zachodu, w: Swojskość i cudzoziemszczyzna w dziejach kultury polskiej, red. Z. Stefankowska, Warszawa 1973, s. 186-231.

${ }^{28}$ A. Giller, op. cit., t. 1, s. 244.

${ }^{29}$ Zob. W. Dutka, Żydzi w historiografii i piśmiennictwie rocznicowym powstania styczniowego w latach 1864-1918. Próba charakterystyki, „Kwartalnik Historii Żydów” 2008, 2 (226), s. 144-151.

${ }^{30}$ Zob. H. Głębocki, Co zrobić z Polską? Imperium i kwestia polska w ideologii konserwatywnej nacjonalizmu Michaiła Katkowa, w: idem, Kresy Imperium. Szkice i materiały do dziejów polityki Rosji wobec jej peryferii, Kraków 2006, s. 245-306.

${ }^{31}$ A. Giller, op. cit., t. 2, s. 158; podobną ocenę wiele lat później zaprezentował także biograf Romualda Traugutta, Marian Dubiecki, pisząc, że „żołnierz polski powinien mieć wiarę szczerą i gorącą, ale bez fanatyzmu i pobożność prawdziwą bez bigoterii". Por. M. Dubiecki, Bohaterski naczelnik powstania styczniowego, Warszawa 1918, s. 38.

32 Por. Z. Zieliński, Mit „Polak-katolik”, w: Polskie mity polityczne XIX i XX wieku, red. W. Wrzosek, Wrocław 1994, s. 107-117; E. Jabłońska-Deptuła, Samoobronny model „Polaka-Katolika" i jego wpływ na stosunek do mniejszości narodowych, w: Trudna tożsamość. Problemy narodowościowe i religijne w Europie Środkowo-Wschodniej XIX i XX wieku, Lublin 1996, s. 62-71; B. Porter-Szücs, op. cit., s. 328-359. 
ligijną ludzi go tworzących. Tolerancja religijna, szacunek wobec różnorodności wyznaniowej, jest śmiałą propozycją, jak na ówczesne polskie warunki ${ }^{33}$. Halina Florkowska-Frančić podkreśliła, że związki Gillera z duchowieństwem, których podstawą był paradygmat polityczny - Kościół z narodem, przez cały okres życia i politycznej działalności Gillera były bardzo żywe ${ }^{34}$. Warto dodać, że Giller jako jedyny z uczestników dyskursu o powstaniu styczniowym został zauważony w najnowszej książce Briana Portera i przy okazji błędnie nazwany Antonim ${ }^{35}$.

Kolejnym apologetą polskiego Kościoła zaangażowanego politycznie w powstaniu styczniowym był Stefan Buszczyński (1821-1892) ${ }^{36}$, ziemianin, uczestnik powstania, zwolennik czerwonych i egzaltowany katolik. Reprezentował on skrajną, w porównaniu do apologii Gillera, wizję historii powstania styczniowego. Twierdził, że decyzja zamknięcia kościołów jesienią 1861 r. była w pełni uzasadniona, ponieważ celem cara było od samego początku zniszczenie Kościoła i katolicyzmu ${ }^{37}$. Wypowiedź ta konsekwentnie wynikała z przyjętych założeń ideologicznych. Buszczyński, z czym zgadza się autor ostatniej wydanej o nim pracy Krzysztof Kamil Daszyk, interpretował powstanie $1863 \mathrm{r}$. w kategoriach walki „krzyża chrystusowego z carskim bagnetem", czyli patrzył na powstanie poprzez pryzmat historii świętej, pełnej chwalebnych czynów ${ }^{38}$. Duchowieństwo zostało ukazane jako obrońca narodu polskiego. W odniesieniu do arcybiskupa Felińskiego stwierdził, że uległ on tylko chwilowo „wpływowi faryzeuszów i nieprzyjaciół narodowo-religijnej walki”" ${ }^{\prime 9}$, ale już wobec innych przedstawicieli duchowieństwa polskiego sprzeciwiających się powstaniu, Buszczyński miał jedynie słowa potępienia. Pisał tak między innymi o zmartwychwstańcu Hieronimie Kajsiewiczu, któremu zarzucił, iż „popełnił zbrodnię" i „całą piękną przeszłość swoją" sponiewierał ${ }^{40}$. Kajsiewicz został uznany za zdrajcę z powodu słynnego listu ze stycznia $1863 \mathrm{r}$., do „braci w kapłaństwie grzesznie spiskujących”. Drugim duchownym za-

${ }^{33}$ Można nawet mówić, iż w XIX w. upowszechniło i utrwaliło się pojęcie „Polak-katolik”. Taki Polak stał się synonimem „swojego”, przeciwstawianemu „obcemu”, czyli zaborcy, innowiercy. Por. I. Kabzińska, Czy zmierzch stereotypu Polak-katolik?, w: Kultura i świadomość etniczna Polaków na wschodzie. Tradycja i współczesność, red. A. Kuczyński, M. Michalska, Wrocław 2004, s. 192; B. Porter-Szűcs, op. cit., s. 328-359.

${ }^{34}$ H. Florkowska-Frančić, op. cit., s. 210.

${ }^{35}$ B. Porter-Szücs, op. cit., s. 215, 225-226.

${ }^{36}$ M. Dynowska, Buszczyński Stefan, PSB, t. 3, Kraków 1937, s. 147-149; Buszczyński Stefan, w: Literatura polska. Przewodnik encyklopedyczny, t. 1, Warszawa 1984, s. 124;

K. K. Daszyk, Strażnik romantycznej tradycji. Rzecz o Stefanie Buszczyńskim, Kraków 2001.

${ }^{37}$ S. Buszczyński, Obrona spotwarzonego narodu, t. 1, Kraków 1888, s. 23.

${ }^{38}$ K. K. Daszyk, op. cit., s. 210-215.

${ }^{39}$ S. Buszczyński, op. cit., t. 1, s. 38.

${ }^{40}$ Ibidem, s. 100-105. 
atakowanym przez Buszczyńskiego był ks. Walerian Kalinka (1826-1886), jeden z twórców historycznej szkoły krakowskiej. Buszczyński namiętnie zwalczał historyków tej szkoły ${ }^{41}$, a ks. Kalinka był dla niego „fałszywym prorokiem" fałszywej wiary ${ }^{42}$. Dostało się także duchowieństwu galicyjskiemu. Arcybiskup metropolita lwowski ksiądz Franciszek Wierzchlejski (1803-1884) zabronił odprawiania nabożeństw patriotycznych w kościołach po tym, jak władze austriackie wprowadziły na terenie Galicji stan wojenny w marcu $1864 \mathrm{r}^{43}$ Dla autora Obrony spotwarzonego narodu każdy głos przeciw powstaniu równał się zdradzie, a postawa duchowieństwa galicyjskiego była nie do zaakceptowania, chociaż wynikała z nacisków władz austriackich. Ideałem księdza-patrioty i męczennikiem był Stanisław Brzóska ${ }^{44}$.W przekonaniu pisarza udział duchowieństwa w powstaniu był powszechny, tak jak jego poparcie dla Komitetu Centralnego. Stanowisko to stoi w sprzeczności z nowszymi ustaleniami historyków ${ }^{45}$.

Legendy 1863 r. bronił także Jan Stella-Sawicki (1831-1911) ${ }^{46}$, w czasie powstania jego żołnierz, organizujący aprowizację oddziałów powstańczych w Galicji, a także wybitny lekarz i propagator higieny w drugiej połowie XIX w. Zapatrzony w romantyczny ideał Polski - Chrystusa narodów, Stella-Sawicki (jak wcześniej Zborowski, którego broszurę mógł znać) porównywał manifestacje patriotyczne z 1861 r. do wypraw krzyżowych:

Były to chwile tak wzniosłe, że chyba je porównać z przede dniem krzyżowych wojen, kiedy każdy powtarzał „tak Bóg chce, tak Bóg chce” i szedł naprzód, bez wahania, bez namysłu, nie pytając, nie obliczając, dokąd zawiedzie go droga i jaka przyszłość czeka... ${ }^{47}$.

${ }^{41}$ Zob. K. K. Daszyk, op. cit., s. 215.

${ }^{42}$ S. Buszczyński, op. cit., t. 1, s. 109.

${ }^{43}$ Ibidem, s. 113.

${ }^{44}$ Osoba ks. Brzóski urosła do postaci niezwykłej rangi w nurcie apologetycznym. W broszurze zatytułowanej Powstanie styczniowe 1863 roku poddane pod sad żyjacych i potomnych na pamiątkę 25 rocznicy, wydanej w Krakowie w 1888 r., Buszczyński przedstawił hagiograficzno-martyrologiczną wizję życia i śmierci duchownego.Pisał, że „ksiądz ten należał do rzędu tych postaci, co zimne rozumy nazywają fanatykami, a lud czci jako świętych". W opinii E. Niebelskiego legenda księdza Brzóski łączyła w sobie ideał chrześcijańskiego rycerza i świętego kapłana. Buszczyński widział w tej postaci przede wszystkim świętego sprawy narodowej. Por. S. Buszczyński, Powstanie styczniowe 1863 roku poddane pod sąd żyjacych i potomnych na pamiątkę 25 rocznicy, Kraków 1888, s. 63; E. Niebelski, Legenda księdza powstańca Stanisława Brzóski, w: Epilog styczniowej insurekcji 1863 roku, red. idem, Lublin 2006, s. 82.

${ }^{45}$ Por. S. Kieniewicz, Powstanie styczniowe, Warszawa 1983, s. 318; E. Niebelski, Duchowieństwo lubelskie i podlaskie w powstaniu 1863 roku i na zesłaniu w Rosji, Lublin 2002, s. 156.

${ }^{46}$ S. Kieniewicz, M. Domańska-Nogajczyk, Jan Stella-Sawicki (1831-1911), PSB, t. 43, Kraków 2004-2005, s. 352-357.

${ }^{47}$ [J. Stella-Sawicki], Szkice z powstania 1863 roku nakreślone przez pułkownika Strusia, Kraków 1889, s. X. 
W kolejnym dziele Stella poświęcił cały rozdział manifestacjom religijno-patriotycznym. Cechą tej narracji jest wszechobecny patos i podkreślenie jedności wszystkich bez wyjątku Polaków, do których mieli dołączyć też „Żydzi, naród tak zmaterializowany” ${ }^{48}$. W ostatniej pracy poświęconej powstaniu Galicja w powstaniu styczniowym znalazł się po raz pierwszy krytyczny wątek. Stella-Sawicki skrytykował postawę galicyjskiego duchowieństwa, które powstania poprzeć nie chciało, a zwłaszcza biskupa krakowskiego Antoniego Gałeckiego, który zabronił rozpowszechniania odezwy Rządu Narodowego skierowanej do proboszczów ${ }^{49}$. Krytyka duchowieństwa galicyjskiego za postawę zachowawczą i lojalistyczną łączy poglądy Stelli-Sawickiego i Buszczyńskiego.

Z kolei Józef Ignacy Kraszewski (1812-1887) ${ }^{50}$ w swej publicystyce pozytywnie oceniał zaangażowanie duchowieństwa w powstanie i poprzedzające je wydarzenia. W broszurze wydanej w Paryżu w 1862 r. pisał:

Widziano starych i wiernych sług carskich rzucających urzędy, posady i dygnitarstwa i przechodzących na stronę narodu, ludzi zużytych niewolą otrząsających jarzmo i wyznających prawdę, kobiety uzbrojone siłą męczeńską, dzieci zapałem namaszczone na wodzów; powaśnionych podających sobie ręce, umarłych razem z Ojczyzną powstających z grobu... gorączkę ofiary opanowującą tłumy jak w pierwszych wiekach chrześcijaństwa, cuda, o jakich nikt nie śmiałby był marzyć przed rokiem ${ }^{51}$.

Dla Kraszewskiego manifestacje religijne w Warszawie w $1861 \mathrm{r}$. równały się męczeństwu pierwszych chrześcijan. Motyw ten odnajdujemy wcześniej tylko u Kotkowskiego i Zborowskiego. Kraszewski wierzył, że ofiara z życia poniesiona dla ojczyzny daje pewność zmartwychwstania. Owe pozytywne spojrzenie na powstanie styczniowe, jako na wojnę religijną, znalazło także potwierdzenie w serii publicystycznej Rachunki z lat 1867-1869, napisanej ostrym językiem politycznej pasji. Wyczuwalna jest kategoria uwznioślenia (sublime):

Takie naprężenie ducha, musiało w istocie tworzyć istoty i czyny gdzie indziej niesłychane, niemożliwe. Trwało ono aż do 1861 roku, w którym

${ }^{48}$ [J. Stella-Sawicki], Szkice z powstania 1863 roku, s. 40; o udziale Żydów w powstaniu styczniowym z perspektywy historiografii powstańczej zob. W. Dutka, op. cit., s. $144-151$.

${ }^{49}$ J. Stella-Sawicki, Galicja w powstaniu styczniowym, Lwów 1909, s. 159.

${ }^{50}$ Zob. S. Burkot, Kraszewski - szkice historyczno-literackie, Warszawa 1988; J. Starnawski, Kraszewski wielokrotnie na nowo odczytywany, „Sprawozdania z Czynności i Posiedzeń Naukowych ŁTN" 42, 1988, 5; Kraszewski - pisarz współczesny, red. E. Ihnatowicz, Warszawa 1996; M. Woźniakiewicz, Kraszewskiego wizje przeszłości i przyszłości, Lublin 1997; T. Budrewicz, Kraszewski przy biurku i wśród ludzi, Kraków 2004.

${ }^{51}$ [J.I. Kraszewski], Sprawa polska w roku 1861. List z kraju, Paryż 1862, s. 40. 
zolbrzymiało jeszcze i sprowadziło wybuch $1863 . .$. nacechowany najpotężniejszem uczuciem, jakie kiedykolwiek w piersi ludzkiej mieszkało. Szał święty młodzieży ogarnął naówczas wszystkich lub przynajmniej odebrał wszystkim siłę opierania mu się, chociaż przeważna większość narodu przewidywała, jakie za sobą skutki miało pociągnąć powstanie... ${ }^{52}$.

Egzaltowana narracja Kraszewskiego przedstawiała powstańczą walkę polskiej młodzieży w sposób podobny do przedstawienia męczeństwa duchowieństwa. Jednak, co najciekawsze, zdaniem pisarza Rosja dostrzegła, że to właśnie polski Kościół katolicki jest jej największym wrogiem, może nawet potężniejszym niż powstańcy:

Ofiarą tego oporu legalnego, poczytywanego za bunt przeciwko władzy, padli ks. arcybiskup Feliński, Krasiński, Rzewuski, Domagalski, Szczygielski i niezliczone ofiary... na ostatek Kaliński biskup chełmski unicki, który zmarł na wygnaniu. Dziś konsystorz unicki jest w ręku jawnie sprzyjających syzmie. Rząd rosyjski rozumie to dobrze, iż katolicyzm jest dlań główną zaporą do zupełnego owładnięcia Polską. Oderwać ją od Europy nie można inaczej jak zrywając ten węzeł, co ją łączy ze społecznością cywilizowaną; nie można ociemnieć i zniżyć aby,jak Katków chce, zrównać z zacofaną Rosją tylko gasząc pochodnią religii ${ }^{53}$.

Oderwać Polskę od jej religii to oderwać ją od cywilizowanej Europy, zdawał się podpowiadać czytelnikom Kraszewski. Można odnaleźć w narracji Kraszewskiego ślady postrzegania 1863 r., jako sporu cywilizacji $^{54}$. W takiej narracji Kościół katolicki urósł do rangi fundamentu kulturowego Zachodu przeciwstawianemu złemu Wschodowi ${ }^{55}$. To zarazem motyw okcydentalistyczny, zakładający, że polski Kościół stanowił pierwszą przeszkodę w drodze Rosji na Zachód. Kraszewski zdawał się rozumieć, że różnice między odczuciami polskiego duchowieństwa, szczególnie tego niższego, i poglądami biskupów, dystansujących się od powstania styczniowego, mieściły się w jednym i tym samym katolicyz-

52 [J.I. Kraszewski], Z roku 1866. Rachunki przez B. Bolesławitę, Poznań 1867, s. 51.

${ }^{53}$ Ibidem, s. 65-66.

${ }^{54}$ Poglądy Kraszewskiego na Rosję i jej domniemaną obcość cywilizacyjna i religijną - a nienawidził on prawosławia - będące zapewne owocem jego fascynacji pismami Franciszka Duchińskiego, omawiam szczegółowo w tekście: W. Dutka, Fatalna siła wrogości. Mit obcości i barbarzyństwa Rosji i Rosjan w polskim piśmiennictwie historycznym dotyczacym powstania styczniowego w latach 1863-1918, PH 99, 2008, 3, s. 77-97. Zob. także, K. Stępnik, Zbójca, trup i zwierzę. Stereotypy zaborców w „Rachunkach” i „Programie Polskim” Kraszewskiego, w: Kraszewski pisarz współczesny, s. 85-88.

${ }^{55}$ O negatywnym micie Wschodu w kulturze polskiej XIX w. zob. E. Kuźma, Mit Orientu i kultury Wschodu w polskiej literaturze XIX i XX wieku, Szczecin 1980. 
mie, który był wystarczająco szeroki, aby zmieścić ultramontanów, zachowawcze duchowieństwo, jak i księdza-partyzanta Brzóskę:

Powiedzieliśmy nasz katolicyzm... nie bez rozmysłu... polska wiara bowiem ma swą charakterystykę szczególną, która ludziom surowszym często się aż odszczepieństwem wydaje... Prawda katolicka, dogmat jest jeden, ale nikt nie zaprzeczy, iż różnobarwna ludzkość przez samą słabość swą, bardzo różnie go czuje, praktykuje, wykłada i rozumie... Nie miejsce tu, abyśmy o tem szerzej mówić mogli ${ }^{56}$.

Inny umiarkowany apologeta powstania, Kazimierz Gregorowicz (1833-1889 $)^{57}$, w swoim dziele Poglad krytyczny na wypadki 1861, 1862, 1863 i zaczerpnięte z nich wskazówki polityczne z powodu prac Bolesławity powstałym w odpowiedzi na pisma Kraszewskiego pozytywnie ocenił rolę Kościoła w 1863 r., a ocenę tę łączył z fenomenem polskiej tolerancji religijnej. Nie znaczy to jednak, że dwutomowe dzieło Gregorowicza, jedna z najambitniejszych ówczesnych prac o powstaniu styczniowym, powstało w opozycji do Kraszewskiego. Gregorowicz pisał, że Kraszewski kończył tam, gdzie inni zaczynają ${ }^{58}$. Jednak kładł szczególny nacisk na ideę równouprawnienia religijnego wszystkich mieszkańców ziem dawnej Rzeczypospolitej. Szczytem takiego równouprawnienia były obchodzone 10 października 1861 r. uroczystości ku czci rocznicy unii w Horodle, które opisywał zapewne z perspektywy naocznego świadka. Podczas tej ogólnonarodowej manifestacji bratali się Polacy, Ukraińcy i Żydzi, a księdzem mającym szczególne zasługi dla zorganizowania obchodów rocznicowych w „duchu jagiellońskim” był ukraiński duchowny, Stiepan (Szczepan) Laurysiewicz. Opis uroczystości posłużył wytrawnemu pióru Gregorowicza do spostrzeżeń bardziej ogólnych: powstanie styczniowe udowodniło, iż wolność i religia, uważane w Europie za niemożliwe do pogodzenia, w Polsce były dla siebie nawzajem podporą ${ }^{59}$. Polska i jej wiara katolicka zostały przeciwstawione zeświecczonemu Zachodowi Europy. To motyw zbieżny

56 [ J. I. Kraszewski], Z roku 1867. Rachunki przez B. Bolesławitę, t. 2, cz. 2, Poznań 1868, s. 217.

${ }^{57}$ M. Tyrowicz, Gregorowicz Kazimierz (1833-1889), PSB, t. 8, Wrocław-Kraków-Warszawa 1959-1960, s. 569-570.

${ }^{58}$ Myślę, że możemy mówić o inspiracji. Choć różnic między nimi było sporo (począwszy od idei federacyjnej Europy, której Gregorowicz był gorącym zwolennikiem, skończywszy na ciemiężonym przez carat narodzie rosyjskim, dla którego Gregorowicz miał wiele sympatii, a którego Kraszewski nienawidził), nie różnili się tak bardzo w ocenie zaangażowania niższego kleru katolickiego w powstańczą irredentę. Zob. K. Gregorowicz, Pogląd krytyczny na wypadki 1861, 1862, 1863 i zaczerpnięte z nich wskazówki polityczne. Z powodu prac Bolesławity, t. 1, Kraków 1880, s. 5.

${ }^{59}$ Ibidem, s. 78. 
z poglądami Gillera. W wywodzie Gregorowicza znalazło się przeświadczenie, że sytuacja religijna Polski rozmijała się z ogólnymi tendencjami sekularyzacyjnymi w Europie.

W zainteresowaniach Bolesława Limanowskiego (1835-1935) ${ }^{60}$, nestora polskiej lewicy niepodległościowej, ale i badacza dziejów Polski, problem zaangażowania duchownych w powstanie styczniowe znajdował się na drugim planie. Nie znaczy to, że Limanowski nie wypowiadał się w ogóle na ten temat: napisał cieple słowa o atmosferze, jaka towarzyszyła manifestacjom patriotycznym na wiosnę $1861 \mathrm{r}$. Na nabożeństwo żałobne po Joachimie Lelewelu 29 maja 1861 r. przybyło liczne grono Rusinów do kościoła katolickiego w Kijowie, a w Warszawie w oddaniu hołdu zmarłemu historykowi uczestniczyli Żydzi i katolicy ${ }^{61}$. W opinii Limanowskiego postawa ta płynęła z ogólnoludzkiego braterstwa, a nie z przekonań religijnych. Jednocześnie miał on świadomość, iż używanie religii do celów politycznych niosło ze sobą duże ryzyko:

Jedni rozmiłowali się w manifestacjach i w męczeństwie i gotowi byli mniemać, że krzyżem i śpiewem zdołają wypędzić najazd z kraju. Słusznie już wówczas ostrzegano, że „,modłami i śpiewami nie odzyskamy tego, co modły i śpiewy lub ślepa żarliwość zaprzepaściły" ${ }^{\text {"2 }}$.

Z zaangażowanych w powstańczą walkę duchownych Limanowski odnotował mówiącego wyłącznie po litewsku ks. Antoniego Mackiewicza (Antanas Mackevičius) ze Żmudzi, co nie może dziwić, ponieważ postać tego duchownego znakomicie wpisywała się do głoszonej przez Limanowskiego koncepcji 1863 r. jako „wojny ludowej”. Limanowski przedstawił też działania w powstaniu i śmierć ks. Brzóski, ukazując go jako nieustraszonego obrońcę ludu wiejskiego. Tak jak Mackiewicz, Brzóska był księdzem pochodzącym z ludu.

${ }^{60}$ Podstawowa literatura: M. Handelsman, Bolesław Limanowski jako badacz historii powszechnej, PH 33, 1935, 1, s. 328-333; idem, Bolesław Limanowski. Teoria naukowa, w: idem, Historycy. Portrety i profile, Warszawa 1937, s. 32-41; W. Tokarz, Bolesław Limanowski, PH 33, 1935, 1, s. 326-327; H. Wereszycki, Bolesław Limanowski, PSB, t. 17, s. 340-346; J. Kurczewska, Dwie postawy wobec kryzysu ethosu demokratyczno-patriotycznego. Bolesław Limanowski i Zygmunt Balicki, Warszawa 1975; Nestor polskiego socjalizmu czy tylko demokrata? Studia o Bolesławie Limanowskim, red. S. Michalkiewicz, Katowice 1987; M. Wróbel, Socjalizm humanistyczny Bolesława Limanowskiego, Warszawa 1988; M. Śliwa, Bolesław Limanowski. Człowiek i historia, Kraków 1994; J. Bardach, Nieznana autobiografia Bolesława Limanowskiego, w: idem, W obiektywie nauki i lustrze pamięci (o uczonych, pisarzach, politykach XIX i XX wieku), Warszawa 2004, s. 54-67; K. Cottam, Bolesław Limanowski, w: Nation and History. Polish historians from the Enlightenment to Second World War, red. P. Brock, Toronto 2006, s. 101-113.

${ }^{61}$ B. Limanowski, Historia ruchu narodowego od 1861 do 1864 r., t. 1, Lwów 1882, s. 104.

${ }^{62}$ Ibidem, s. 105. 
Z okresu przed wybuchem pierwszej wojny światowej pochodzi jeszcze jeden warty odnotowania głos historyka amatora. Należał on do Józefa Dąbrowskiego „Grabca” (1876-1926) ${ }^{63}$. W swej najwcześniejszej pracy poświęconej powstaniu, Rok 1863, wydanej na pięćdziesiątą rocznicę tragicznego Stycznia, napisał, że od samego początku powstania duchowieństwo polskie miało wielki wpływ na polskie społeczeństwo ${ }^{64}$, a także, iż duchowieństwo w znakomitej większości poparło powstanie, czego przejawem miała być działalność ks. Karola Mikoszewskiego „Sykstusa”65. Wyznając tezę o licznym poparciu powstania przez polskie duchowieństwo, Grabiec-Dąbrowski znalazł także kilka ciepłych słów dla arcybiskupa Felińskiego. Pisał, że arcybiskup ten postępował samodzielnie, nie dbając ani o zadowolenie rządu, ani schlebianie rewolucji ${ }^{66}$. Oceniał też bardzo pozytywnie zjednoczenie sił duchowieństwa i czerwonych, których nazywał partią rewolucyjną. Historyk pisał, że okres manifestacji zakończył w ten sposób czas najdziwniejszego sojuszu rewolucji z Kościołem katolickim, będącym zawsze stróżem porządku społecznego. Był ten sojusz możliwy, przekonywał Grabiec-Dąbrowski, tylko w tak strasznie anormalnych warunkach, jakie panowały w roku 1863, stając się logiczną konsekwencją dzikiej i niszczycielskiej polityki rosyjskiej na ziemiach dawnej Polski ${ }^{67}$. W kolejnej pracy wydanej w 1917 r., zatytułowanej Powstanie styczniowe, historyk powtórzył swoje wcześniejsze stanowisko, według którego „duchowieństwo niższe stanęło murem za narodem i poparło powszechnie ruch narodowy" ${ }^{68}$. Można stwierdzić, że przekonanie o powszechności udziału duchowieństwa katolickiego w powstaniu styczniowym utrwaliło się wraz z rokiem 1918.

\section{Krytycznym okiem}

Z lat sześćdziesiątych XIX w. pochodzi opinia Pawła Popiela (1807-1892) ${ }^{69}$ krakowskiego konserwatysty, który oceniając zaangażowanie duchowieństwa katolickiego po stronie powstania, stwierdził z wyraźną irytacją, że

${ }^{63}$ J. Feldman, Józef Grabiec-Dąbrowski, PSB, t. 5, Kraków 1939-1946, s. 12-14.

${ }^{64}$ J. Grabiec [J. Dąbrowski], Rok 1863, Poznań 1913, s. 49.

${ }^{65}$ Ibidem, s. 223; zob. też. R. Bender, Ksiądz Karol Mikoszewski, (ks. „Syxtus”) 1832-1886, Warszawa 1982. Co ciekawe, dobrego zdania o księdzu Mikoszewskim nie miał Walery Przyborowski, który pisał o nim „ów Sykstus rewolucyjny, ksiądz wywłoka, zawsze był zwolennikiem najskrajniejszych ludzi” wśród „czerwieńców”. Por. [W. Przyborowski], Dzieje 1863 roku, t. 1, Kraków 1897, s. 36.

${ }^{66}$ J. Grabiec [J. Dąbrowski], op. cit., s. 159.

${ }^{67}$ Ibidem, s. 163-164.

${ }^{68}$ J. Grabiec [J. Dąbrowski], Powstanie styczniowe 1863-1864, Warszawa 1917, s. 31.

${ }^{69}$ L. Dębicki, Paweł Chościak Popiel, Kraków 1892; M. Sokołowski, W. Łuszczkiewicz, Paweł Popiel, Kraków 1893; L. Tarnowski, Paweł Popiel jako pisarz, Kraków 1894; S. Kieniewicz, 
duchowieństwo polskie było wychowane „w podejrzliwości, bez biskupów, bez karności, bez dostatecznej nauki". Popiel doszedł do wniosku, że duchowni nie potrafili w czasie manifestacji patriotycznych z 1861 r. odróżnić patriotyzmu i zwykłej politycznej hipokryzji ${ }^{70}$. Ten mocny emocjonalny zarzut wyrastał przede wszystkim z wielkiej troski Popiela o sprawy Kościoła. Jak przekonuje autor najnowszej pracy o nim, Jacek Kloczkowski, związek pomiędzy Kościołem katolickim i myślą polityczną Popiela był bardzo ścisły ${ }^{71}$. Jako zagorzały przeciwnik idei powstańczej (choć w powstaniu na jego polecenie wzięli udział jego synowie) nie mógł pisać dobrze o zaangażowaniu weń duchowieństwa. Patriotyzm Popiela to przede wszystkim zgoda na lojalizm i poszukiwanie w ramach tegoż trudnej, bo rozbiorowej „,wolności wewnętrznej”, którą przed ponad dwudziestu laty opisał trafnie Marcin Król ${ }^{72}$. W ocenie krakowskiego konserwatysty duchowieństwo poparło ruch rewolucyjny głównie z braku karności i wykształcenia, a także z powodu politycznej nieświadomości. W jego przekonaniu w 1863 r. wykorzystano naiwną pobożność ludu, co samo w sobie nosiło zalążki działania sprzecznego $\mathrm{z}$ duchem religii ${ }^{73}$. Dostrzegł też, że czerwonym udało się przeciągnąć na swoją stronę sporą część duchowieństwa oraz opinii publicznej ${ }^{74}$.

W sukurs Popielowi, ale w tonie jeszcze ostrzejszym wypowiedział się Henryk Lisicki (1839-1899) ${ }^{75}$, biograf margrabiego Aleksandra Wielopolskiego, historyk samouk. W $1880 \mathrm{r}$. wdał się on w publiczną polemikę z hrabią Stanisławem Tarnowskim, jednym z przywódców krakowskich

Paweł Popiel, PSB, t. 28, Wrocław-Kraków-Warszawa 1984-1985, s. 568-572; J. Forst-Battaglia, Paweł Popiel, w: Twórcy polskiej myśli politycznej. Zbiór studiów, red. J.S. Miś, Wrocław 1978, Polska Myśl Polityczna XIX i XX Wieku, t. 2, s. 7-29; E. Rostworowski, Popioły i korzenie. Szkice historyczne i rodzinne, Kraków 1985, s. 295-310; J. Kloczkowski, Wstęp, w: P. Popiel, Choroba wieku. Wybór pism, oprac. J. Kloczkowski, Kraków 2001; idem, Polscy konserwatyści wobec tradycji insurekcyjnej. Dziewiętnastowieczne dylematy, w: Póki my żyjemy. Tradycje insurekcyjne w myśli polskiej, red. idem, Warszawa 2004; idem, „Wolność i porządek. Myśl polityczna Pawła Popiela”, Kraków 2004 (mps).

${ }^{70}$ P. Popiel, Kilka stów z powodu odezwy x. Sapiehy, Kraków 1864, s. 24.

${ }^{71}$ J. Kloczkowski, „Wolność i porządek”, s. 35.

${ }^{72}$ Por. Stańczycy. Antologia myśli społecznej i politycznej krakowskich konserwatystów, oprac. M. Król, Warszawa 1985, s. 15-17,

${ }^{73}$ P. Popiel, op. cit., s. 54.

${ }^{74}$ Literatura przedmiotu jest zgodna co do tego, że sukcesem czerwonych było udane przeciągnięcie na swoją stronę niższego duchowieństwa. Por. S. Kieniewicz, Powstanie styczniowe, s. 248-287; E. Niebelski, Duchowieństwo lubelskie i podlaskie, s. 166.

${ }^{75}$ Zob. W. Stankiewicz, Henryk Lisicki, PSB, t. 17, s. 450-451; S. Schnür-Pepłowski, Henryk Lisicki, KH 13, 1899, s. 178-181; A. Szwarc, Od Wielopolskiego do Stronnictwa Polityki Realnej. Zwolennicy ugody z Rosja, ich poglądy i próby działalności politycznej (1864-1905), Warszawa 1996. 
konserwatystów ${ }^{76}$. Lisicki, przeczytawszy broszurę Tarnowskiego o swoim dziele poświęconym Wielopolskiemu, odpowiedział własnym tekstem, zatytułowanym Domowe sprawy. Napisał w nim, że w 1861 r. odczuwał coraz większe obrzydzenie do teatralnych obrzędów w kościele, w których było bardzo mało religijnego uczucia ${ }^{77}$. Religia to teatr polityczny - to kolejny zarzut konserwatystów pod adresem zaangażowanego politycznie duchowieństwa. Lisicki był zdania, że błędem Kościoła było identyfikowanie katolicyzmu z miłością ojczyzny oraz z nienawiścią do Rosji. W ocenie publicysty chłód Watykanu wobec powstania styczniowego był właśnie tym powodowany ${ }^{78}$. Lisicki uznał zaangażowanie Kościoła w powstanie za błąd polityczny. Demonizując siłę spisku czerwonych, pisał, że spiskowcy użyli szatańskiego pomysłu: wykorzystali religię do celów politycznych. Narzekał wreszcie, iż „,naród, wierzący i pobożny, wewnętrznego życia religijnego nie znał"79. Lisicki skrytykował ostro czerwonych za przeciągnięcie na stronę ruchu rewolucyjnego części duchowieństwa diecezjalnego i zakonnego. Dowodził, że duchowieństwo szło „na pasku spiskowców". Księża zakonni zachęcali do noszenia żałoby narodowej. Tym samym duchowieństwo miało przyczynić się do wzrostu nastrojów rewolucyjnych ${ }^{80}$. W ocenie biografa margrabiego Kościół ponosił część odpowiedzialności za ferment rewolucyjny i w dalszej konsekwencji za doprowadzenie do tragicznego, bezsensownego militarnie i politycznie powstania. W odróżnieniu od oceny Gillera, podkreślającego zmianę stanowiska abp. Felińskiego, Lisicki nazwał tego hierarchę „kapłanem cichych cnót i głębokiej nauki"81. 0 innych duchownych Lisicki nie wypowiedział się.

Udziałowi i postawom duchowieństwa polskiego wobec zrywu styczniowego dużo miejsca poświęcił także pisarz i historyk Walery Przyborowski (1845-1913) ${ }^{82}$. W swojej pierwszej pracy o powstaniu napisanej

${ }^{76}$ W. Łazuga, Stanisław Tarnowski publicysta, w: idem, Rzeczy większe i mniejsze, Poznań 2002, s. 123-137.

${ }^{77} \mathrm{H}$. Lisicki, Domowe sprawy. Odpowiedź hr. Stanisławowi Tarnowskiemu z powodu biografii Aleksandra Wielopolskiego, Kraków 1880, s. 2.

${ }^{78}$ Ibidem, s. 106.

${ }^{79}$ H. Lisicki, Aleksander Wielopolski 1803-1877, t. 1, Poznań 1878, s. 136.

${ }^{80}$ Ibidem, s. 192.

${ }^{81}$ Ibidem, s. 299.

82 J. Cieślikowski, Walerego Przyborowskiego powieść historyczna dla dzieci, „Studia Pedagogiczne" 5, 1958, s. 123-146; J. Detko, Powstanie styczniowe w twórczości pisarzy minorum gentium, w: Dziedzictwo literackie powstania styczniowego, Warszawa 1964; J. Figarska, Uwagi do biografii Walerego Przyborowskiego, „Przegląd Humanistyczny” 21, 1977, 6, s. 173-174; Historiografia polska $w$ dobie pozytywizmu, s. 112; K. Groniowski, Walery Przyborowski - historyk powstania styczniowego, „Rocznik Świętokrzyski” 2, 1971, s. 203-208; S. Mijas, Trubadur wolności, w: idem, Świętokrzyskie szlaki literackie, Łódź 1973, s. 118-130; 
pod słynnym pseudonimem Z.L.S. pisarz zawarł tezę, iż duchowieństwo polskie oddało się sprawie powstania całkowicie i dobrowolnie ${ }^{83}$. Przyborowski łatwo ulegał namiętnościom politycznym i pisał tonem egzaltowanym w najwyższym stopniu. Dzięki tej kategorii narracyjnej, którą nazwałbym hiperbolizacją, zbudował głębszą warstwę opowieści o polskiej religijności w $1863 \mathrm{r}$. Według pisarza owa religijność była pozorna, łatwo ulegająca namiętnościom politycznym i pozbawiona głębszej treści intelektualnej i duchowej ${ }^{84}$. W monumentalnym dziele Historia dwóch lat poświęconym okresowi manifestacji patriotycznych pisarz ten zaprezentował bardzo krytyczną ocenę polskiego duchowieństwa:

Samo duchowieństwo zresztą, od czasów osławionej mowy Wielopolskiego do przedstawicieli kleru, przyjęło względem nowego swego zwierzchnika postawę wrogą i wyraźnie brało udział w ruchu rewolucyjnym. Duchowieństwo niższe, proboszcze i wikariusze, zamieszkali po wsiach i miasteczkach, wszystkie prawie zakony, ciemne, niewykształcone, rekrutujące się przeważnie z drobnego mieszczaństwa lub ludu, nienawidzące Moskali jako schizmatyków, przepełnione fanatyzmem nietolerancyjnym, lgnęło do ruchu, który budził w nich wszystkich uśpione uczucia zagorzałego i ślepego patriotyzmu ${ }^{85}$.

Przyborowski doszukiwał się przyczyn nienawiści niższego duchowieństwa zakonnego do Rosjan, próbując wykazać, że duchowieństwo było takie, jakie było społeczeństwo. Stawiając duchowieństwu zarzut nienawiści do Rosjan, sam zdradzał stanowisko silnie naznaczone niechęcią do tego narodu ${ }^{86}$. Pisarz dostrzegł, że ów niższy kler parafialny i zakonny stanowił o sile stronnictwa czerwonych. Wyraził nawet pogląd, że to dzięki duchowieństwu „partia rewolucyjna” uzyskała wpływ na duszę ludu wiejskiego:

Rzecz prosta, że najsilniejszym narzędziem po temu stało się niższe duchowieństwo, fanatycznie i patriotycznie usposobione, które widocznie przechylało się do rewolucji i chętnie wszelkie zlecenia agitatorów wypełniało.Jako potężny środek ku temu służył konfesjonał, a nade wszyst-

S. Kieniewicz, G. Skotnicka, Walery Przyborowski, PSB, t. 29, Wrocław-Kraków-Warszawa 1985-1986, s. 81-84; B. Cioch, „Walery Przyborowski - historyk, literat, publicysta”, Opole 1994 (praca doktorska, mps); idem, Walery Przyborowski w ocenie współczesnych i potomnych, „Zeszyty Naukowe Uniwersytetu Opolskiego”, Historia, 1996, z.32; Walery Przyborowski i Józef Brandt. Materiały z konferencji, red. K. Stępnik, M. Gabryś, Lublin 2007.

${ }^{83}$ Z.L.S. [W. Przyborowski], Wspomnienia ułana z roku 1863, Poznań 1874, s. 4.

${ }^{84}$ Podobne argumenty przeciw Kościołowi podnosili socjaliści. Por. A. Chwalba, Sacrum i rewolucja. Socjaliści polscy wobec praktyk i symboli religijnych (1870-1918), Kraków 2007.

${ }^{85}$ Z. L.S. [W. Przyborowski], Historia dwóch lat, t. 2, Kraków 1893, s. 423.

${ }^{86}$ Zob. W. Dutka, Fatalna siła, s. 440-445. 
ko kazalnica, z której, nawet w tej porze jeszcze, mimo stanu wojennego, rozlegały się głośne potępienia ${ }^{87}$.

W ocenie Przyborowskiego, piszącego historię powstania styczniowego z perspektywy polityki ugodowej końca XIX w., duchowieństwo niższe stało się rzecznikiem rewolucji społecznej. Pisarz ten powielał charakterystyczne struktury narracyjne: jeśli pisał o niższym duchowieństwie, to nie inaczej niż „ciemnym i fanatycznym”. Nawet jeśli Przyborowski nie rozmijał się z prawdą co do udziału niższego duchowieństwa zakonnego $\mathrm{w}$ powstaniu ${ }^{88}$, potrafił przekazywać w narracji historycznej swoje emocje i dominowały one nad treścią faktograficzną. Dostrzegł, iż czerwoni uzyskali nad budzącym się ruchem powstańczym niezaprzeczalną władzę w chwili, kiedy przeciągnęli na swoją stronę niższy kler. Przyborowski dodał także, że Rosjanie czuli się bezsilni wobec tego sojuszu niższego duchowieństwa i radykałów dążących do powstania ${ }^{89}$. Ów ciekawy wątek, w jaki sposób Rosjanie widzieli zaangażowanie duchownych, spotkać można na kartach ostatniego, monumentalnego dzieła Przyborowskiego poświęconemu upadkowi powstania styczniowego:

W ostatnim powstaniu, zwłaszcza w jego periodzie przygotowawczym, duchowieństwo polskie wysunęło się nieomal na pierwszy plan, i jeżeli były takie chwile, w których rząd szamotał się w bezsilnym gniewie, to chwile te stworzył kler polski ${ }^{90}$.

Pisarz tak krytyczny wobec idei powstańczej jak Przyborowski dostrzegł, że katolicyzm stanowił narodowe decorum Polaków. Rosjanie odczuwali, że w 1863 r. pierwszoplanową rolę odegrał Kościół i katolicyzm rozumiany jako idea powstańcza. W jego charakterystyce można wyodrębnić także drugą płaszczyznę. Była nią ocena poszczególnych duchow-

${ }^{87}$ W. Przyborowski, Historia sześciu miesięcy. Ustęp z dziejów 1862 roku, Petersburg 1901, s.170.

${ }^{88}$ Literatura przedmiotu, zwłaszcza ta najnowsza, potwierdza fakt silnego zaangażowania patriotycznego niższego duchowieństwa zakonnego w powstanie.Podaję najważniejsze pozycje bibliograficzne: E. Jabłońska-Deptuła, J. Gawrysiakowa, Materiały do zaangażowania patriotycznego zakonów męskich w Królestwie Polskim 1861-1864, w: Materiały do historii zgromadzeń zakonnych na ziemiach polskich w XIX i na początku XX wieku, Lublin 1976, s. 51-200; E. Orzechowska, Z działalności patriotycznej bernardynów w Radomiu w dobie powstania styczniowego, w: Zakony franciszkańskie w Polsce, t. 3, red. J. Kłoczowski i in., Niepokalanów 1996; E. Niebelski, Duchowieństwo lubelskie i podlaskie; A.J. Szteinke, Zaangażowanie patriotyczne męskich zakonów franciszkańskich w XIX wieku na przykładzie reformatów, w: Dzieło świętego Franciszka z Asyżu. Projekcja w kulturze i duchowości polskiej XIX i XX wieku, red. D. Kielak, J. Odziemkowski, J. Zbudniewek, Warszawa 2004, s. 421-445.

${ }^{89}$ Z.L.S. [W. Przyborowski], Historia dwóch lat, t. 2, s. 426.

${ }^{90}$ Idem, Ostatnie chwile powstania styczniowego, t. 3, Poznań 1888, s. 254. 
nych, zarówno należących do ścisłej hierarchii, jak i niższego duchowieństwa. 0 abp. Felińskim miał Przyborowski dobre zdanie i poświęcił mu wiele miejsca ${ }^{91}$. Krytycznie pisał o tych, którzy rzucali na Felińskiego kalumnie:

Szkalowano go, opluwano, nazwano zdrajcą i biskupem moskiewskim, nie szczędzono mu żadnych obelg i żadnych ciosów. Jakież męczarnie musiała przechodzić ta dusza czysta, rozmarzona, zapatrzona w Polskę [--] Ale był to dopiero początek, pierwsze krople cykuty, którą pić miał z czasem pełnym kielichem ${ }^{92}$.

Przyborowski antycypował tym samym późniejsze losy arcybiskupa, zesłanego do Rosji. Z jego opisów wyłania się postać ascetyczna, skromna, pobożna i niepodlegająca politycznym wpływom czerwonych. Nawet gdy arcybiskup w końcu sprzeciwił się Rosjanom, Przyborowski miał o nim wyłącznie dobre zdanie. Charakteryzując innych przedstawicieli hierarchii kościelnej, pisarz stwierdził, że biskup kujawsko-kaliski Michał Marszewski odprawił uroczyste nabożeństwo z okazji wydania dekretu uwłaszczeniowego w Królestwie zakończone odśpiewaniem pieśni Boże, cara chrani ${ }^{93}$. Przy okazji charakterystyki tego hierarchy stwierdził, że opowiadał się on za potępieniem powstania przez Kościót ${ }^{94}$. Przyborowski uznał taką postawę za godną szacunku. Warto jednak zaznaczyć, że podczas manifestacji patriotycznych w $1861 \mathrm{r}$. biskup Marszewski był często nazywany zdrajcą, a podczas jego wizyty w Łęczycy obrzucono go nawet śniegiem ${ }^{95}$. Przyborowski zgadzał się, że potępienie ruchu powstańczego przez Kościół było pożądane. Nie może nas to dziwić. Pisarz potępiał wszak powstanie jako takie, co jednak nie przeszkodziło mu zająć jednoznacznie negatywnego stanowiska wobec duchownych, okrywających się podczas powstania złą sławą. Na przykład dla ks. Pawła Kamińskiego ${ }^{96}$, jednego z kapelanów wojsk Mariana Langiewicza, a potem

${ }^{91}$ Idem, Historia dwóch lat, t. 4, Kraków 1895, s. 35, passim.

${ }^{92}$ Ibidem, s. 61.

${ }^{93}$ Idem, Ostatnie chwile powstania styczniowego, t. 2, Poznań 1887, s. 68.

${ }^{94}$ W. Przyborowski, Historia sześciu miesięcy, s. 337.

${ }^{95}$ Zob. E. Niebelski, Łęczycki incydent biskupa Marszewskiego 3 IX 1861 roku, w: Religie. Edukacja. Kultura. Księga pamiatkowa ofiarowywana prof. Stanisławowi Litakowi, red. M. Surdacki, Lublin 2002, s. 217-222.

${ }^{96}$ Ks. P. Kamiński po upadku powstania wydał potwarczą broszurę o 1863 r., zatytułowaną Przyczynek do historii polskiej 1861-1864, Paryż 1866. Owa broszura spotkała się z bardzo ostrą krytyką A. Gillera w dziele Historia powstania narodu polskiego 1861-1864. Ks. Kamiński był także autorem innej broszury, zatytułowanej Duchowieństwo polskie wobec sprawy narodowej. Giller datował wydanie tego tekstu na 1865 r., a Przyborowski na 1867 . W obu przypadkach historycy powstania zgadzają się, że miejscem wydania 
odstępcy i potwarcy powstania, znalazł tylko słowa potępienia, nazywając go „księdzem wywłoką, intrygantem zawołanym i kanalią"98. Co ciekawe, Przyborowski, zwykle potępiający czerwonych, miał też dobre zdanie o księżach-męczennikach: ks. Antonim Majewskim, zamordowanym pod Grochowiskami przez Rosjan, lub o kapucynie, o. Agrypinie Konarskim, straconym na stokach warszawskiej Cytadeli w czerwcu 1863 r. Natomiast najsłynniejszego księdza-partyzanta, S. Brzóskę, uznał Przyborowski za wybitnego żołnierza. To pewna niekonsekwencja, ponieważ innym partyzantom nie szczędził złośliwości. Warto podkreślić, że Przyborowski miał już świadomość legendy i mitu, jakie otaczały tego bohaterskiego księdza".

Nie sposób nie wspomnieć o poglądach Stanisława Koźmiana (1836$1922)^{100}$, wybitnego przedstawiciela stronnictwa stańczyków. Wspominałem ostatnio, że Koźmianowi bardzo nie podobało się zaangażowanie polityczne duchowieństwa w manifestacje patriotyczne i działalność Rządu Narodowego ${ }^{101}$. O wadze problemu dla Koźmiana świadczy fakt, iż w okresie przygotowywania się do napisania dzieła Rzecz o roku $1863 \mathrm{roz}-$ kolportował badawczą ankietę wśród przyjaciół i osób postronnych, a jedno z pytań dotyczyło zaangażowania białych w manifestacje religijne aprobowane przez Kościół ${ }^{102}$. Mimo to w dziele Koźmiana Rzecz o roku 1863 tematyka duchowieństwa znalazła się na drugim planie. Jego ocena wykazuje podobieństwa z ogólnymi ocenami Przyborowskiego. Krakowski pisarz stwierdził, że duchowieństwo stanęło po stronie ruchu rewolucyjnego po masakrze 8 kwietnia $1861 \mathrm{r}^{103}$ Jednak sukces wszechwładnego spisku, w którego istnienie Koźmian wierzył naprawdę latem 1861 r., był związany z postawą duchowieństwa:

Udziałem wyższego i niższego duchowieństwa w demonstracjach i ruchu, przybierał on znamiona religijne, które roznamiętniały, rozgorącz-

był Paryż. Giller poddał ten tekst surowej krytyce, stwierdzając, że był on „bałamutny i krzywdzący" dla polskiego duchowieństwa.

98 [W.Przyborowski], Dzieje 1863 roku, t. 2, Kraków 1899, s. 185-188.

${ }_{99}$ Por. Z.L. S. [W. Przyborowski], Ostatnie chwile powstania styczniowego, t. 1, Poznań 1887, s. 150-153; E. Niebelski, Legenda, s. 81.

100 Z. Jabłoński, J. Zdrada, Stanisław Koźmian, PSB, t. 15, Wrocław-Kraków-Warszawa 1970, s. 61-66; A. Bar, Teatr krakowski pod dyrekcją Koźmiana, Lwów 1939; S. K. Rostworowski, Stanisław Koźmian i rok 1863, „Przegląd Polski i Obcy” 2, 1958, 4, s. 93-98; J. Got, Stanisław Koźmian, w: Literatura polska, t. 1, s. 488; zob. S. Koźmian, Bezkarność. Wybór pism, oprac. B. Szlachta, Kraków 2001.

${ }^{101}$ W. Dutka, Stanisław Koźmian (1836-1922) wobec powstania styczniowego, „Przegląd Humanistyczny" 54, 2010, 4, s. 75-89.

102 BPAU-PANKr, rkps 2045, k. 85, passim.

103 S. Koźmian, Rok 1863, t. 2, Warszawa 1903, s. 198. 
kowywały i poetyzowały go [--]. Duchowieństwo, ani zbyt wykształcone, ani do karności przywykłe, podzielało uczucia i złudzenia powszechne [--] Demonstracje z ulic i placów publicznych, przeniosły się do kościołów, nabrały były coraz jaskrawszych pozorów religijnych ${ }^{104}$.

Koźmian stanął na stanowisku, że duchowieństwo, popierając dążenia czerwonych, nie miało koniecznej politycznej świadomości, ponieważ, jak czytamy, było „niewykształcone, ani do karności przywykłe”. To ocena zbieżna z poglądami Popiela. Szczególną irytację Koźmiana budził fakt, że znaczna część duchownych opowiedziała się za powstaniem. Zarazem był on świadomy, jak wielkie niebezpieczeństwo dla samego katolicyzmu stanowiło wykorzystanie tegoż do celów politycznych. Wydaje mi się, że to najdonioślejsza teza Koźmiana płynąca z obserwacji zaangażowania religii w rok 1863:

Żadna religia, nawet jeżeli ma być dźwignią polityczną, środkiem być nie może, lecz musi pozostać sama dla siebie celem, nie szczegółem życia, lecz wszystkiem w życiu - i dlatego także jeżeli ma pozostać siłą istotną, do żadnych, prócz własnych celów używaną być nie może ${ }^{105}$.

Koźmian rozumował, iż religia należy do sfery sacrum i nie powinna być wykorzystywana politycznie pod żadnym pozorem. Do tej tezy warto odnieść słowa Magdaleny Micińskiej, która pisząc o ideologicznych fundamentach światopoglądu konserwatystów, stwierdziła, że dla nich „rdzeniem polskości była wiara katolicka"106. Jednak katolicyzm na usługach stronnictwa czerwonych w powstaniu styczniowym najwyraźniej nie mieścił się w tym fundamencie. Koźmian, jako krakowski konserwatysta, pisząc krytycznie o zaangażowaniu katolicyzmu i jego instrumentalizacji w 1863 r., bronił katolicyzmu przed rozpolitykowanym duchowieństwem. Jak przekonywał niegdyś Andrzej Jaszczuk, , ,katolicyzm w interpretacji konserwatystów spełniał dwie funkcje: był przede wszystkim deklaracją utrzymania związku z kulturą europejską oraz akceptacji tradycji" ${ }^{107}$. Koźmian widział w katolicyzmie ideową rękojmię utrzymania konserwatywnego charakteru kultury polskiej, ale sprzeciwiał się ostro wykorzystaniu religii w polityce, jeśli ta polityka prowadziła do szaleńczego powstania przeciw Rosji, niemającego żadnych szans powodzenia.

${ }^{104}$ Ibidem, s. 278.

105 S. Koźmian, Rok 1863, t. 3, Warszawa 1903, s. 357.

${ }^{106}$ M. Micińska, Zdrada córka nocy. Pojęcie zdrady narodowej w świadomości Polaków 1861-1864, Warszawa 1998, s. 127.

107 A. Jaszczuk, Spór pozytywistów konserwatystami o przyszłość Polski 1870-1903, Warszawa 1986, s. 131. 
Włodzimierz Spasowicz (1829-1906) ${ }^{108}$, redaktor petersburskiego czasopisma „Kraj”, ubolewał nad faktem, że wojna polsko-rosyjska z 1863 r.miała podłoże religijne. Winą za ten stan rzeczy obarczał duchowieństwo polskie, które nie potrafiło stanąć na wysokości zadania, zwodzone przez radykałów (czerwonych).Kler katolicki - jak stwierdził Spasowicz nie bez swoistej ironii - tak przywykły do opłakiwania upadku wpływu Kościoła na sprawy świeckie, uległ pokusie władzy nad ruchem, podczas gdy to czerwoni zdołali sprzęgnąć religię z namiętnościami narodowymi ${ }^{109}$.W ocenie Spasowicza ten stan rzeczy powodował "najzgubniejsze i najniebezpieczniejsze” konsekwencje, a duchowieństwo, szczególnie to niższe, nie potrafiło odróżnić emocji politycznych od wiary. Spasowicz, nota bene prawosławny Polak, dostrzegał także, że pomiędzy polskim powstaniem a katolicyzmem istniało iunctim trudne do zrozumienia dla Rosjan. Można także domniemywać, że przebywając na stałe w Petersburgu i wykładając przez pewien czas na tamtejszym uniwersytecie, Spasowicz zgadzał się z rosyjskimi wyobrażeniami na temat ścisłej korelacji polskiego katolicyzmu z politycznym i duchowym życiem Polaków w Królestwie. Redaktor naczelny „Kraju” obserwował bowiem wnikliwie rosyjskie życie umysłowe, bardzo interesował się poglądami Władimira Sołowjowa (Vladimir Solov'ëv) i rosyjskich liberałów dotyczącymi sprawy polskiej ${ }^{110}$. Spasowicz krytykował zaangażowanie duchowieństwa w politykę, jednak powstrzymał się od wskazywania konkretnych osób.

Sporo ciekawych wniosków wniósł do dyskusji August Sokołowski (1846-1921) ${ }^{111}$. Historyk ten przedstawił najbardziej wyważoną ocenę wyższego duchowieństwa polskiego w czasie powstania. Nowością było to, że dostrzegł i uznał dramatyzm politycznego położenia biskupów polskich podczas powstania styczniowego. Biskupi pozbawieni możliwości stałego kontaktu ze Stolicą Apostolską, ograniczeni w wypełnianiu obowiązków,

${ }^{108}$ Zob. M. Jankowski, Być liberałem w czasie trudnym. Rzecz o Włodzimierzu Spasowiczu, Łódź 1996; M. Król, Włodzimierz Spasowicz, w: idem, W. Karpiński, Od Mochnackiego do Piłsudskiego. Sylwetki polityczne XIX wieku, Warszawa 1997; A. Jaszczuk, Czy Włodzimierz Spasowicz był zdrajca narodu?, KH 101, 1994, 2, s. 11-25; J. Bardach, Spasowicz Włodzimierz (1829-1906), PSB, t. 41, Warszawa-Kraków 2002, s. 45-53; idem, Włodzimierz Spasowicz, w: idem, W obiektywie nauki i lustrze pamięci (o uczonych, pisarzach, politykach XIX i XX wieku), Warszawa 2004, s. 301-320.

${ }^{109}$ W. Spasowicz, Życie i polityka margrabiego Wielopolskiego, w: idem, Pisma, t. 3, Petersburg 1892, s. 108.

110 Sołowjow przekazał nawet Spasowiczowi egzemplarz z dedykacją swojej pracy Kwestia narodowościowa $w$ Rosji. Zob. A. Walicki, Rosja, katolicyzm i sprawa polska, Warszawa 2002, s. 181.

111 U. Pechowska, Sokołowski August, PSB, t. 40, Warszawa-Kraków 2000-2001, s. 117-120; Historiografia polska $w$ dobie pozytywizmu, s. 120. 
pilnowani i podejrzewani na każdym kroku, nie mogli sprawować swoich urzędów z pożytkiem dla Kościoła i wiary ${ }^{112}$. Sokołowski dostrzegł też, niezależnie od krytycznej oceny 1863 r., że biskupi nawet gdyby chcieli, nie mogliby otwarcie poprzeć powstania. Byli zakładnikami swoich urzędów i pozycji społecznej. Autor ten wypowiedział się także o abp. Felińskim. Charakteryzując jego osobę, dostrzegł, że nie był on „człowiekiem z powietrza wziętym" i że nominowanie go na tron arcybiskupów warszawskich było dobrym rozwiązaniem ${ }^{113}$. Historyk pisał także o tym, że abp Feliński został źle przyjęty zarówno przez czerwonych, którzy go nienawidzili, jak też przez krakowski, konserwatywny „Czas”114. Gdy jednak Rosjanie pogwałcili sakralność kościołów jesienią 1861 r., arcybiskup potrafił się ostro sprzeciwić $^{115}$.W interpretacji Sokołowskiego hierarchę tego miała przerażać wizja powtórki z rabacji galicyjskiej, dlatego początkowo dystansował się od powstania.

\section{Podsumowanie}

Druga połowa XIX w. charakteryzowała się złożonymi postawami wobec polskiej sprawy niepodległościowej. Jeszcze w 1863 r. duża część duchownych wykazywała sympatie ultramontańskie, w przypadku zaś biskupów mieliśmy do czynienia z postawą biernego wyczekiwania na rozwój wypadków, dystansu wobec powstańców. Wątek polskiego duchowieństwa i roli, jaką ta grupa społeczna odegrała w powstaniu styczniowym, należy ocenić jako jeden z istotniejszych wątków w sporze o rok 1863. Pozytywna bądź krytyczna ocena zaangażowania patriotycznego duchownych w irredentę była pochodna politycznych lub ideologicznych zapatrywań, jakim hołdowali poszczególni pisarze i historycy piszący o powstaniu ${ }^{116}$.

Giller bronił udziału duchowieństwa w 1863 r. dowodząc, że stanęło ono $\mathrm{w}$ większości za narodem. Jest to stanowisko bliskie mitowi rozpropagowanemu przez czerwonych. Na skrajnym, bliskim czerwonym, stanowisku stali Buszczyński i Kotkowski. W ich narracjach można doszukać się romantycznej egzaltacji patriotycznej oraz idealizacji roli duchowieństwa podczas powstania. $\mathrm{Z}$ kolei pisarze z kręgu ideowych przeciwników powstania, tacy jak Popiel, Lisicki, w mniejszym stopniu Koźmian i Spasowicz, krytykowali udział duchowieństwa z tych samych powodów, dla których Giller go bronił. Koźmian, krytykując zaangażowanie duchowień-

\footnotetext{
${ }^{112}$ A. Sokołowski, Powstanie styczniowe, Wiedeń 1910, s. 117.

113 Ibidem, s. 141-144.

${ }^{114}$ Ibidem, s. 145.

115 Ibidem, s.161.

116 O stosunku lewicy do Kościoła w okresie po 1863 r.zob. A. Chwalba, op. cit..
} 
stwa w powstanie styczniowe, bronił autonomii religii i pragnął widzieć ją jako sferę sacrum, z dala od polityki. Wśród krytyków najbardziej barwną, choć niepozbawioną tendencyjności ocenę zaprezentował Przyborowski. Pisząc na ogół krytycznie o duchowieństwie, potrafił zachować nieco dystansu i pozytywnie ocenić zarówno abp. Felińskiego, jak i ks. Brzóskę (o tym drugim wyrażali się z uznaniem egzaltowany Buszczyński i zachowujący rezerwę wobec Kościoła socjalista Limanowski). Sokołowski zauważył natomiast, że biskupi stali się więźniami swojej pozycji, byli bowiem uzależnieni od władz zaborczych, więc nie mogli podejmować radykalnych kroków. Wśród krytyków panowała także opinia, że katolicyzm, odgrywając w 1863 r. rolę polityczną, pogłębił różnice między Polakami i Rosjanami.

Jednak tuż przed odzyskaniem niepodległości górę w dyskursie wziął mit. Prace Grabca-Dąbrowskiego, znamionujące przewartościowanie w ocenie powstania styczniowego u progu niepodległości, poświadczają, że myślenie o masowym udziale duchowieństwa w powstaniu zdobyło w polskiej historiografii $1863 \mathrm{r}$. trwałe miejsce ${ }^{117}$. Wydaje się, że zarówno Grabiec-Dąbrowski, jak i Marian Dubiecki ulegli sile mitu stworzonego i rozpowszechnionego przez czerwonych. Było to przekonanie tak silne, że trwa po dziś dzień, choć ostatnio - szczęśliwie zostało sfalsyfikowane ${ }^{118}$.

Takie stanowisko dominowało także w XX w., choć próbowano analizować zagadnienie udziału duchownych z różnych perspektyw badawczych. Wymiar rocznicowy historiografii powstańczej, w tym spory wynikające z bieżącej sytuacji politycznej choćby z okazji przypadającej w 1913 r. pięćdziesiątej rocznicy tragicznego Stycznia, przedstawiła z dobrym skutkiem Lidia Michalska-Bracha ${ }^{119}$. Dopiero w ostatnich latach pojawiła się opinia,że „rola duchowieństwa była wyjątkowa i wyróżniająca duchownych spośród innych grup Królestwa Polskiego, ale wypracowała ją znaczna mniejszość,

${ }^{117}$ Dobrym przykładem takiego myślenia jest opinia Dawida Fajnhauza piszącego, że „powstanie poparła ogromna większość duchowieństwa katolickiego”. Zob. D. Fajnhauz, 1863 - Litwa i Białoruś, Warszawa 1999, s. 183.

${ }^{118}$ E. Niebelski, Jakiś zadziwiający duch powiał na sługi ołtarza (Duchowieństwo katolickie w Królestwie Polskim w roku 1862 wobec Komitetu Centralnego Narodowego), w: Kościót. Społeczeństwo. Kultura. Prace ofiarowane prof. Wiesławowi Müllerowi z okazji pięćdziesięciolecia pracy naukowej i dydaktycznej, red. J. Drob, H. Łaszkiewicz, A. Stasiak i in., Lublin 2004, s. 485.

119 Por. L. Michalska-Bracha, Powstanie styczniowe w pamięci zbiorowej społeczeństwa polskiego w okresie zaborów, Kielce 2003; eadem, Rocznicowy wymiar historiografii powstania styczniowego przełomu XIX i XX stulecia. O kategoriach „uobecniania” czasu historycznego, „Historyka” 34, 2004, s. 107-121; eadem, Między pamięcią a historiografią. Lwowskie debaty o powstaniu styczniowym (1864-1939), Kielce 2011. 
natomiast nie ogół kleru" ${ }^{120}$. Przekonania o masowym udziale duchowieństwa w powstaniu styczniowym należy ocenić jako mit ${ }^{121}$, warto jednak zaznaczyć, że ów mit był nieodłącznym budulcem legendy powstania.

\section{The Roman Catholic Clergy and Catholicism as a Topic for a Controversy about the January Uprising in Polish Historiography 1863-1918}

The author's intention is to demonstrate the complex historiographical discussion about the stance of the Catholic clergy and the involvement of the institutional Catholic Church in the January Uprising as well as the national movement preceding the insurrection. The discussion was composed of two distinct motifs - an apology of the participation of the clergy in the uprising and its criticism. This division reflected rifts in the analysed debate held by historians and publicists. The historiography of the January Uprising was intensely polemical. The text analysing the nineteenth-century debate refers also to recent findings made by historiography examining the presence of the clergy in the 1863 rising. The apologetic current presented a wide spectrum of views based on exalted Romantic Catholicism (e.g. Stefan Buszczyński or Jan Stella-Sawicki). The support offered by the Church to the insurrection and the participation of the clergy was also defended in a more disciplined and intellectually cohesive manner (e.g. Kazimierz Gregorowicz). At the same time, historians often regarded the interests pursued by the national community and political Catholicism as identical. The most outstanding participants of the discussion were Walery Przyborowski and Stanisław Koźmian, with the latter defending religion against its politicalisation and arguing that religion, conceived as the domain of the sacrum, should not be applied for even such lofty proposes as the struggle for independence since it turns into its own contradiction.

Translated by Aleksandra Rodzińska-Chojnowska

${ }^{120}$ E. Niebelski, Duchowieństwo lubelskie i podlaskie, s. 413.

${ }^{121}$ Ibidem, s. 409. 